$\underline{\text { ARTICLES }}$

\title{
Publications after conference published studies \\ presentations: A systematic review of
}

\author{
SANDEEP GROVER, DALTON N, SIDDHARTH SARKAR
}

\section{Abstract}

Background and aims: Conferences provide an opportunity to present findings to an audience of experts in the field and get feedback for putting the research in context. Since conference proceedings provide limited space for presenting the findings, research publications are able to provide a better platform for the wider reach, scrupulous peer evaluation, and temporal consolidation of the medical scientific material. This review attempts to collate the studies which have evaluated the abstract publication ratio of the conference presentations.

Methods: The systematic review and meta-analysis included peer reviewed publications which quantitatively reported the publication rate of conference presentations.

Results: A total of 28 studies were included, with sample sizes ranging from 82 to 1897 abstracts (total 17,172 abstracts). The publication rate ranged from $3.8 \%$ to $78.0 \%$, with weighted mean publication rate of $41.8 \%$ (95\% confidence interval of $34.1 \%$ to $49.5 \%$ ). Oral presentations had a greater chance of being published as compared to poster presentations (odds ratio of $2.693,95 \%$ confidence intervals of 1.285 to 5.646). There was high degree of heterogeneity in the findings.

Conclusions: A small proportion of the conference presentations ispublished. Efforts should be made to improve the abstract publication ratio to improve the wider dissemination of the available research.

\footnotetext{
Authors: Sandeep Grover (drsandeepg2002@yahoo.com), Professor, Department of Psychiatry, Post Graduate Institute of Medical Education and Research (PGIMER), Chandigarh $160012 \quad$ INDIA; Dalton N (daltonrajatv@@gmail.com), Senior Resident, Department of Psychiatry, Post Graduate Institute of Medical Education and Research(PGIMER), Chandigarh, 160 012, INDIA; Siddharth Sarkar (sidsarkar22@gmail.com), Assistant Professor, Department of Psychiatry, All India Institute of Medical Sciences (AlIMS), Ansari Nagar, New Delhi, 110029 INDIA

To cite: Grover S, Dalton N, Sarkar S. Publications after conference presentations: A systematic review of published studies. Indian J Med Ethics. 2021 Jan-Mar; 6(1) NS: 25-31. DOI: 10.20529/IJME.2020.106.

Published online first on October 31, 2020.

Manuscript Editor: Sanjay A Pai

Peer Reviewers: Denny John , Aasim Ahmad

( ) Indian Journal of Medical Ethics 2020
}

Keywords: Abstracts, conferences, oral, poster, publication

\section{Introduction}

Conference presentations are an important step in the process of dissemination of scientific findings. These presentations are able to provide a glimpse into the current topical research of interest in the field and also provide an opportunity for discussion and deliberation over the findings (1). Conference presentations also provide a platform for younger researchers to showcase their work and get familiar with the process of dissemination of scientific insights. The natural corollary of conference presentations would be publication in peerreviewed journals (2).

Publication of the conference presentations in journals helps to make scientific material available in a more rigorous manner to a wider audience. The process of peer review during the publication phase provides critical, unfettered inputs for putting the findings in context and spelling out the inaccuracies and limitations. Despite publication being a preferred outcome of conference presentations, not all such presentations are published.There could be several reasons for non-publication, including the waning interest of the researchers, difficulties in securing a reasonable outlet for publication, and/or presentations being of limited academic value. Yet knowing the extent to which research presentations are published would give an estimate of the "translation" of conference presentations into publications.

From an ethical standpoint as well, publication of conference material has two connotations. On the one hand, it can provide information on scientific research undertaken and presented, which in turn, would make available to society in general in a more rigorous format data about patients, thus enabling further scientific discourse. Publication of the abstracts of papers would, therefore, mean justice is being done to the patient time consumed in the process (though it may not apply when secondary data is used). On the other hand, low publication rates of conference proceedings may mean that work being presented is of low scientific interest and may not substantively justify the time of the professionals with regard to the scientific content (though conferences may have other ancillary advantages like 
networking). Further, many institutes financially support their faculty and residents to attend various conferences with the rider that they should have a presentation to make. Little is known about how many of these presentations culminate in full research publications for wider dissemination. To initiate and inform about these considerations, an accurate idea of scientific proceedings being published in the literature is required. Hence, this systematic review and meta-analysis attempts to collate to what extent research presentations are published.

\section{Methods}

The present systematic review utilised the PubMed database to identify studies. Additional studies were identified using the Google Scholar database. Keywords used for the searches in varying combinations were "Conference Proceedings", "abstracts", "publication rate", "abstract publication ratio", "publication ratio", and "publication". The criteria for being included in this systematic review were: the study had to be in English; it had to be published in a peer-reviewed medical journal which had been evaluated with a publication rate for conference presentations; and it should have presented its data in usable quantitative format. Those studies which did not have numerical data of the rate of conference presentations being published were excluded. The search was carried out in March 2019.

To be included in the meta-analysis, the studies were required to present data of abstract publication ratio, that is, provide data about the number of abstracts presented in a conference that were subsequently published. Studies just reporting the content of the abstracts and other related topics were excluded.

Information was extracted from the included studies by two of the authors (SG and ND). Information regarding the author name, name of the conferences, years of the conferences, number of abstracts evaluated, time lag allowed, search engines, and strategies used to identify publications, and publication rate was extracted using a pre-determined proforma. Where available, the publication rates of oral and poster presentations, respectively, were extracted. The extracted data were analysed using OpenMetaAnalyst software. The effect sizes were generated using the proportions method of the software. Weighted mean effect sizes of the entire sample along with $95 \%$ confidence intervals were computed to generate the pooled publication rate. A random effects model was used for computing the overall publication rate. 12 test of heterogeneity was used to ascertain the heterogeneity of the included studies and their effect sizes. Quality of the studies was reported based upon JBI Critical Appraisal Checklist for Studies Reporting Prevalence Data (3).This has nine items and was found to be most closely aligned to the methods of the study. Separate analysis was run to find differences between the publication rate of oral presentations and poster presentations by generating pooled odds ratios and their confidence intervals. Meta-regression using Comprehensive Meta-Analysis software was used to see whether the duration of ascertainment of the publication status (ie waiting for a longer duration after the conference to assess whether an abstract was finally published) had an impact on the publication rate.

\section{Results}

An initial search yielded 479 studies, abstracts of which were screened; of these, 28 were found to fulfil the criteria for the meta-analysis, and these studies were included (Table1 and Figure $\left.{ }^{*}\right)$. The number of abstracts in the included studies ranged from 82 to 1897 , and the total number of abstracts included in all the studies, cumulatively, added up to 17,172 . The publication rate ranged from $3.8 \%$ to $78 \%$, with weighted mean publication rate of $41.8 \%$ (95\% confidence interval of $34.1 \%$ to $49.5 \%$ ), as shown in Figure $2^{*}$. Four studies had explicitly compared publication rates of oral and poster presentations. Oral presentations had a greater chance of being published as compared to poster presentations (odds ratio of $2.693,95 \%$ confidence intervals of 1.285 to 5.646 ) (Figure ${ }^{*}$ ).

The time frame for assessment of publication was available for 23 studies and ranged from 2 to 8 years.

The regions of the conference(s) and the field and quality analysis of the studies are presented in Table 2. Most of the conferences included in the review were held in North America, followed by Europe, and then other countries. The most common fields of medicine were radiology, followed by orthopaedics. Most of the studies were fair in quality, while the item in which many studies faltered was "Were valid methods used for the identification of the condition?" A funnel plot was drawn to find evidence of publication bias (Figure $4^{*}$ ), and the distribution of the studies did not suggest publication bias.

Meta-regression was used to ascertain whether greater duration in the time frame of assessment or publication year was associated with greater publication rate (Table 3).

Random effects model was used due to high heterogeneity, and separate meta-regression analyses were carried out for each of the two variables with the publication rate. However, the duration of time frame available did not predict the publication rate. Also, publication year did not have a significant impact on the publication rate (Table 3).

Subgroup analyses were conducted to find whether the region of the conference or the discipline was related to publication rates (Figures 5 and 6, respectively). It was seen that presentations in North America/ United States had higher publication rates than those in Europe, which in turn had greater publication rates than those in other regions. Also, when comparing fields, gastroenterology conference presentations had the highest publication rates, while primary care had the lowest. However, these were represented by one study each. 


\begin{tabular}{|c|c|c|c|c|c|c|}
\hline \multicolumn{7}{|c|}{$\begin{array}{c}\text { Table 1: } \\
\text { Summaries of the studies }\end{array}$} \\
\hline Authors & Names of the conferences & $\begin{array}{l}\text { Years of the } \\
\text { conferences }\end{array}$ & $\begin{array}{l}\text { Number of } \\
\text { abstracts } \\
\text { evaluated }\end{array}$ & \begin{tabular}{|l} 
Time lag \\
allowed
\end{tabular} & $\begin{array}{l}\text { Search engines } \\
\text { and strategies } \\
\text { used to identify } \\
\text { publications }\end{array}$ & \begin{tabular}{|l} 
Publication \\
rate (only those \\
published as full \\
articles)
\end{tabular} \\
\hline $\begin{array}{l}\text { Gorman, Oder } \\
\text { daet al, } 1990 \text { (4) }\end{array}$ & $\begin{array}{l}\text { American Association of } \\
\text { Poison Control Centers, } \\
\text { The American Academy } \\
\text { of Clinical Toxicology, The } \\
\text { American Board of Medical } \\
\text { Toxicology, and the } \\
\text { Canadian Association of } \\
\text { Poison ControlCenters }\end{array}$ & 1984 and 1986 & 296 & & MEDLARS & Total: $49.8 \%$ \\
\hline $\begin{array}{l}\text { Scherer et al, } \\
1994 \text { (5) }\end{array}$ & $\begin{array}{l}\text { Association for Research } \\
\text { in Vision and Ophthalmolo- } \\
\text { gy or the American } \\
\text { Acadmy of Ophthalmology } \\
\text { annual meetings }\end{array}$ & 1988,1989 & 149 & 3 years & MEDLINE & $\begin{array}{l}66 \% \text { of the } \\
\text { confirmed RCT } \\
\text { abstracts } \\
\text { published }\end{array}$ \\
\hline $\begin{array}{l}\text { Wang et al, } 1999 \\
\text { (6) }\end{array}$ & $\begin{array}{l}\text { North American Spine } \\
\text { Society (NASS), Scoliosis } \\
\text { Research Society (SRS), } \\
\text { and International Society } \\
\text { for the Study of the } \\
\text { Lumbar Spine (ISSLS). }\end{array}$ & $\begin{array}{l}\text { NASS } 1990 \text { to } \\
1992, \text { SRS } 1991 \\
\text { to } 1993, \text { and } \\
\text { ISSLS } 1991 \\
\text { to } 1993\end{array}$ & 1186 & $\begin{array}{l}\text { NASS: } 8 \text { years; } \\
\text { SRS and ISSLS: } \\
7 \text { years }\end{array}$ & $\begin{array}{l}\text { Melvyl Medline } \\
\text { Plus }\end{array}$ & \begin{tabular}{|l|} 
Overall: $43.5 \%$ \\
(NASS: $40 \%$ SRS: \\
47 \% ISSLS: 45\%)
\end{tabular} \\
\hline Roy et al, 2001 (7) & $\begin{array}{l}\text { The Oto-rhino-laryngolocal } \\
\text { Research Society (ORS) } \\
\text { meetings, UK }\end{array}$ & 1978 to 1995 & 660 & 456 & MEDLINE & Total. 69.09\% \\
\hline $\begin{array}{l}\text { Sprague et al, } \\
2003 \text { (8) }\end{array}$ & $\begin{array}{l}\text { Meeting of the American } \\
\text { Academy of Orthopaedic } \\
\text { Surgeons. }\end{array}$ & 1996 & 465 & Not known & $\begin{array}{l}\text { MEDLINE, } \\
\text { PubMed }\end{array}$ & Total: $15.48 \%$ \\
\hline $\begin{array}{l}\text { Arrive et al, } 2004 \\
\text { (9) }\end{array}$ & $\begin{array}{l}\text { Radiological Society of } \\
\text { North America }\end{array}$ & 1995 & 1897 & $1-5$ years & MEDLINE & Total:33\% \\
\hline $\begin{array}{l}\text { Miguel-Dasit et al, } \\
2006(10)\end{array}$ & $\begin{array}{l}\text { European Congress of } \\
\text { Radiology }\end{array}$ & 2000 & 1020 & 5 years & MEDLINE & Total: $47 \%$ \\
\hline $\begin{array}{l}\text { Secil et al, } 2006 \\
\text { (11) }\end{array}$ & $\begin{array}{l}\text { European Society of } \\
\text { Gastrointestinal and } \\
\text { Abdominal Radiology } \\
\text { (ESGAR) meetings }\end{array}$ & 2000,2001 & 276 & 4 years & $\begin{array}{l}\text { MEDLINE, } \\
\text { PubMed }\end{array}$ & Total: $39.5 \%$ \\
\hline $\begin{array}{l}\text { Macmillan et al, } \\
2007 \text { (12) }\end{array}$ & $\begin{array}{l}\text { British Association of } \\
\text { Emergency Medicine and } \\
\text { the Faculty of Accident and } \\
\text { Emergency Medicine }\end{array}$ & 2001,2002 & 404 & 3 years & Ovid & \begin{tabular}{|l|} 
Total: $30 \%($ Oral \\
papers: $57 \%$ \\
Posters: $14 \%)$
\end{tabular} \\
\hline Ha et al, 2008 (13) & $\begin{array}{l}\text { Annual meetings of the } \\
\text { Korean Radiological Society } \\
\text { (KRS) and abstracts } \\
\text { presented by Korean } \\
\text { investigators at the annual } \\
\text { meetings of the Radiologi- } \\
\text { cal Society of North Amerca } \\
\text { (RSNA) and European } \\
\text { Congress of Radiology } \\
\text { (ECR) }\end{array}$ & 2001,2012 & 1,097 & 7.6 years & \begin{tabular}{|l|} 
PubMed, Korean \\
Medical Database
\end{tabular} & $\begin{array}{l}\text { Total: } 27.4 \% \text { (KRS: } \\
\text { 23.6\% RSNA: } 35.4 \% \\
\text { ECR }: 50.5 \%)\end{array}$ \\
\hline $\begin{array}{l}\text { Kottachchi et al, } \\
2010(14)\end{array}$ & $\begin{array}{l}\text { Randomized Clinical Trials } \\
\text { in Inflammatory Bowel } \\
\text { Disease Presented } \\
\text { at Digetive Disease Week }\end{array}$ & $1998-2003$ & 82 & & $\begin{array}{l}\text { MEDLINE, } \\
\text { PubMed, } \\
\text { EMBASE, Google } \\
\text { Scholar }\end{array}$ & Total: 78\% \\
\hline
\end{tabular}




\begin{tabular}{|c|c|c|c|c|c|c|}
\hline \multicolumn{7}{|c|}{$\begin{array}{c}\text { Table } 1 \text { continued: } \\
\text { Summaries of the studies }\end{array}$} \\
\hline Authors & Names of the conferences & $\begin{array}{l}\text { Years of the } \\
\text { conferences }\end{array}$ & $\begin{array}{l}\text { Number of } \\
\text { abstracts } \\
\text { evaluated }\end{array}$ & $\begin{array}{l}\text { Time lag } \\
\text { allowed }\end{array}$ & $\begin{array}{l}\text { Search engines } \\
\text { and strategies } \\
\text { used to identify } \\
\text { publications }\end{array}$ & $\begin{array}{l}\text { Publication } \\
\text { rate (only those } \\
\text { published as full } \\
\text { articles) }\end{array}$ \\
\hline $\begin{array}{l}\text { Donegan and Kim, } \\
2012(15)\end{array}$ & $\begin{array}{l}\text { American Academy of Orthopaedic } \\
\text { Surgery (AAOS) }\end{array}$ & 2001 & 756 & 5 years & PubMed, MEDLINE, & $\begin{array}{l}\text { Total: } 49 \% \text { (Poster } \\
\text { presentations : } 47 \% \\
\text { Podium presenta } \\
\text { tions: } 52 \%)\end{array}$ \\
\hline $\begin{array}{l}\text { Winnik et al, } 2012 \\
\text { (16) }\end{array}$ & $\begin{array}{l}\text { European Society of Cardiology } \\
\text { Congress }\end{array}$ & 2006 & 1020 & 4 years & MEDLINE & $\begin{array}{l}\text { Overall: } 31 \%(38 \% \\
\text { for accepted } \\
\text { papers and } 24 \% \\
\text { for rejected } \\
\text { papers) }\end{array}$ \\
\hline $\begin{array}{l}\text { Yoon et al., } 2012 \\
\text { (17) }\end{array}$ & $\begin{array}{l}\text { Urological Society of Australia and New } \\
\text { Zealand (USANZ) Annual Scientific } \\
\text { Meeting }\end{array}$ & 2005 to 2009 & 614 & 3 years & PubMed & Total: $29.8 \%$ \\
\hline $\begin{array}{l}\text { Walsh et al, } 2013 \\
\text { (18) }\end{array}$ & $\begin{array}{l}\text { North American medical education } \\
\text { coferences (Research in Medical } \\
\text { Education Conference [RIME] and the } \\
\text { Canadian Conference on Medical } \\
\text { Education [CCME]) }\end{array}$ & 2005 and 2006 & 449\# & 6.3 years & $\begin{array}{l}\text { MEDLINE, EMBASE, } \\
\text { ERIC, Google } \\
\text { Scholar }\end{array}$ & Total: $34.7 \%$ \\
\hline $\begin{array}{l}\text { Jorgens et al, } \\
\text { 2014(19) }\end{array}$ & $\begin{array}{l}\text { European Association of } \\
\text { studies of Diabetes }\end{array}$ & 2004 & 493\#\# & 4 years & $\begin{array}{l}\text { MEDLINE Authors } \\
\text { contacted by email }\end{array}$ & \begin{tabular}{|l} 
Total: $42.4 \%$ \\
$(51.1 \%$ for \\
accepted \\
abstracts and \\
$26.7 \%$ \\
for rejected \\
abstracts)
\end{tabular} \\
\hline $\begin{array}{l}\text { Mutlu et al, } 2015 \\
\text { (20) }\end{array}$ & $\begin{array}{l}\text { National Congress of Child } \\
\text { and Adolescent Psychiatry } \\
\text { (NCCAP), Turkey }\end{array}$ & $2005-2008$ & $214 \$$ & 5 years & $\begin{array}{l}\text { PubMed, Google } \\
\text { Academic } \\
\text { databases }\end{array}$ & Total $25.2 \%$ \\
\hline $\begin{array}{l}\text { Elliott et al, } 2016 \\
(21)\end{array}$ & $\begin{array}{l}\text { Annual meeting of the } \\
\text { Congress of Neurological } \\
\text { Surgeons, Canada, } 2005\end{array}$ & 2005 & 754 & 5.3 years & $\begin{array}{l}\text { MEDLINE, Scopus, } \\
\text { Google Scholar }\end{array}$ & Total: $50.8 \%$ \\
\hline Kay et al, 2016 (22) & $\begin{array}{l}\text { American Shoulder and } \\
\text { Elbow Surgeons' (ASES) } \\
\text { annual meetings }\end{array}$ & $2005-2010$ & 266 & 5 years & $\begin{array}{l}\text { PubMed, Ovid, } \\
\text { EMBASE }\end{array}$ & Total: $49.2 \%$ \\
\hline $\begin{array}{l}\text { Shergill et al, } \\
2017(23)\end{array}$ & $\begin{array}{l}\text { Cardiovascular and } \\
\text { Interventional Radiology } \\
\text { Society of Europe (CIRSE) } \\
\text { and the Society of } \\
\text { Interventional Radiology } \\
\text { (SIR). }\end{array}$ & 2012 & 421 & 3 years & $\begin{array}{l}\text { PubMed and } \\
\text { Google Scholar }\end{array}$ & Total: $44.9 \%$ \\
\hline $\begin{array}{l}\text { Hosseini-Zijoud, } \\
2017(24)\end{array}$ & $\begin{array}{l}\text { First International Congress } \\
\text { of Nephrology and Urology, } \\
\text { Tehran, Iran, } 2015\end{array}$ & 2015 & 210 & 1 year & $\begin{array}{l}\text { Scopus, PubMed } \\
\text { ISC (for Persian } \\
\text { language pub } \\
\text { lished papers) }\end{array}$ & \begin{tabular}{|l|} 
Total: $23.3 \%$ Oral \\
papers: $41.3 \%$ \\
Posters: $15.6 \%$
\end{tabular} \\
\hline Orr et al, $2017(25)$ & $\begin{array}{l}\text { Society of Military Orthopaedic } \\
\text { Surgeons (SOMOS), USA }\end{array}$ & $2009-2013$ & $592 \$ \$$ & 2 years & PubMed & Total: $58.6 \%$ \\
\hline $\begin{array}{l}\text { Hoelscher et al, } \\
2017 \text { (26) }\end{array}$ & AACAP Annual Meeting, USA & 2012-2013 & 658 & Not known & $\begin{array}{l}\text { PubMed, Google } \\
\text { Scholar }\end{array}$ & Total: $46 \%$ \\
\hline $\begin{array}{l}\text { Basu et al, } 2017 \\
(27)\end{array}$ & $\begin{array}{l}\text { American Academy of Pediatrics, } \\
\text { Pediatric Academic Societies, and } \\
\text { Society of Critical Care Medicine } \\
\text { national meetings. }\end{array}$ & $2007-2011$ & $267 \$ \$ \$$ & 5 years & PubMed search & Total:41\% \\
\hline $\begin{array}{l}\text { Nwachukwu et al, } \\
2018(28\end{array}$ & $\begin{array}{l}\text { International Society for } \\
\text { Hip Arthroscopy (ISHA) }\end{array}$ & $2011-2014$ & 674 & 3 years & $\begin{array}{l}\text { PubMed, MEDLINE, } \\
\text { Google Scholar }\end{array}$ & $\begin{array}{l}\text { Total: } 46.85 \% \\
\text { Podium } \\
\text { presentations: } \\
53.6 \% \text { Poster } \\
\text { presentations } \\
40.1 \%\end{array}$ \\
\hline
\end{tabular}




\begin{tabular}{|c|c|c|c|c|c|c|}
\hline & & $\begin{array}{r}\text { Table } 1 \text { cor } \\
\text { Summaries of }\end{array}$ & $\begin{array}{l}\text { Iued: } \\
\text { studie }\end{array}$ & & & \\
\hline $\begin{array}{l}\text { Egloff et al, } 2017 \\
\text { (29) }\end{array}$ & $\begin{array}{l}\text { Society of General Internal Medicine } \\
2009 \text { Annual Meeting. }\end{array}$ & 2009 & 578 & 5 years & MEDLINE & Total: $47.4 \%$ \\
\hline $\begin{array}{l}\text { Komagamineand } \\
\text { Yabuki, } 2018 \text { (30) }\end{array}$ & $\begin{array}{l}\text { Japan Primary Care Association Annual } \\
\text { Meetings }\end{array}$ & $2010-2012$ & 1003 & 5 Years & MEDLINE & Total: $3.8 \%$ \\
\hline $\begin{array}{l}\text { Raudenbush et al, } \\
2018 \text { (31) }\end{array}$ & North American Spine Society (NASS) & 2009 to 2011 & 671 & 4 years & PubMed & Total: $51 \%$ \\
\hline \multicolumn{7}{|c|}{$\begin{array}{l}\text { \# } 6 \text { abstracts were excluded ( } 4 \text { withdrawn, } 1 \text { missing, } 2 \text { published before abstract deadline) } \\
\text { \#\# Evaluated } 493 \text { out of the } 2008 \text { submitted abstracts, of which } 1306 \text { were accepted for the conference } \\
\$ \text { Included only poster presentation } \\
\$ \$ \text { Excluded poster presentation } \\
\$ \$ \$ \text { Only paediatric critical care medicine abstracts were included }\end{array}$} \\
\hline
\end{tabular}

\section{Discussion}

The two major findings of this meta-analysis are that a substantial proportion of conference presentations may not find an outlet as subsequent publications and that oral presentations are more likely to be published, as compared to poster presentations. Several factors can explain these findings. One, there was considerable heterogeneity across the studies. There were differences in methodology of ascertainment, the duration of follow-up for publication, and the search engines utilised. Yet, even in the best-case scenario, there were several presentations (more than 20\%) that were not published. Thus, it is possible that the authors either are not interested in publication or are not able to secure a suitable journal for publication of their presented material. It is also possible that the presentation was of preliminary material which the authors knowingly withheld from publication, pending the conduct and publication of the full study. Furthermore, sometimes presentations are opportunities for younger members in research teams to present a piece of the entire work, while the more comprehensive results are published together. Hence, while some presentations not being published can be intentional, others may be unintentional.

Oral presentations being published more frequently can be ascribed to several factors. Scientific committees of conferences generally allocate better and more impactful studies to oral presentations (32). Also, oral presentations give more focussed and intense feedback through the discussion during the presentation process. This may provide a first line of peer review for the work under consideration. Furthermore, it can be speculated that those who are less likely to publish the findings per se (due to the preliminary nature of findings or the presentation being a small part of the entire project) are likely to prefer poster presentation.

Publication of conference presentations can be a useful method to enrich the scientific field. The presentation abstract gives leads to researchers working in the field about work done on a particular topic. Access to further details through a scrutinised report in the form of publication can help in planning better research, avoiding the pitfalls experienced previously by others, and developing on the theoretical construct. Thus, encouragement of research publication from conference presentations is desirable. Yet, one of the important functions of academic conferences is facilitation of the meeting and intermingling of a variety of experts in the field, and organisers may be practically constrained for accommodating a range of presentations with myriad perspectives. Hence, expecting all presentations to be duly published might be utopian.

Though the present systematic review and meta-analysis aim to present the publication rate of conference proceedings, some limitations need to be highlighted. The review included only English language papers and excluded those studies where quantification of the publication rate could not be done. Also, there was one study with fair weight but low publication rate, which could have skewed the findings (30). Additionally, we did not look for publication biases or use a structured instrument for assessment of risk of bias. Despite the limitations, the present review presents a collation of findings of the publication rate of presentations made in conferences.

*Note: Figures 1 to 6 are available in the online version of this article from: https://ijme.in/articles/publications-afterconference-presentations-a-systematic-review-of-publishedstudies/

\section{References}

1. Strickland T. Conference presentations with confidence. Case Manager. 1999 Sep-Oct;10(5): 68-70.

2. Turale S. Turning conference presentations into publications. Int. Nurs. Rev.2015 Mar;62(1): 3.

3. Munn Z, Moola S, Lisy K, Riitano D, Tufanaru C. Methodological guidance for systematic reviews of observational epidemiological studies reporting prevalence and cumulative incidence data. Int. J. Evid. Based Healthc. 2015 Sep; 13(3): 147-53.

4. Gorman R L, Oderda G M. Publication of presented abstracts at annual scientific meetings: a measure of quality? Vet. Hum. Toxicol.1990 Oct; 32(5):470-2.

5. Scherer R W, Dickersin K, Langenberg P. Full publication of results initially presented in abstracts. A meta-analysis. JAMA.1994 Jul 13; 272(2):158-62.

6. Wang J C, Yoo S, Delamarter R B. The publication rates of presentations at major Spine Specialty Society meetings (NASS, SRS, ISSLS). Spine (Phila. Pa, 1976). 1999 Mar 1;24(5):425-7.

7. Roy D, Sankar V, Hughes J P, Jones A, Fenton J E. Publication rates of scientific papers presented at the Otorhinolaryngological Research 


\begin{tabular}{|c|c|c|c|c|c|c|c|c|c|c|c|}
\hline \multicolumn{12}{|c|}{$\begin{array}{c}\text { Table 2: } \\
\text { Quality analysis of the included studies }\end{array}$} \\
\hline Authors & Region & Field & Q1 & Q2 & Q3 & Q4 & Q5 & Q6 & Q7 & Q8 & Q9 \\
\hline Gorman and Oderda et al, 1990 (4) & North America/ USA & Toxicology & $\bar{Y}$ & $\bar{Y}$ & $\bar{Y}$ & $\bar{Y}$ & $\bar{Y}$ & $\bar{Y}$ & $\bar{Y}$ & $\bar{Y}$ & $\bar{Y}$ \\
\hline Scherer et al, 1994 (5) & North America/ USA & Ophthalmology & $\mathrm{Y}$ & $\bar{Y}$ & $\mathrm{U}$ & $\mathrm{Y}$ & $\mathrm{Y}$ & $\mathrm{Y}$ & $\bar{Y}$ & $\bar{Y}$ & $\bar{Y}$ \\
\hline Wang et al, 1999 (6) & North America/ USA & Spine & $\mathrm{Y}$ & $\bar{Y}$ & $\bar{Y}$ & $\mathrm{Y}$ & $\mathrm{U}$ & $\bar{Y}$ & $\mathrm{Y}$ & $\bar{Y}$ & $\bar{Y}$ \\
\hline Roy et al., 2001(7) & Other & $\begin{array}{l}\text { Otorhino- } \\
\text { laryngology }\end{array}$ & $\mathrm{Y}$ & $\bar{Y}$ & $\mathrm{Y}$ & $\mathrm{Y}$ & $\mathrm{Y}$ & $\mathrm{U}$ & $\mathrm{Y}$ & $\bar{Y}$ & $\bar{Y}$ \\
\hline Sprague et al., 2003 (8) & North America/ USA & Orthopaedics & $\bar{Y}$ & $\bar{Y}$ & $\mathrm{Y}$ & $\bar{Y}$ & $\bar{Y}$ & $\mathrm{U}$ & $\mathrm{Y}$ & $\bar{Y}$ & $\bar{Y}$ \\
\hline Arrive et al, 2004 (9) & North America/ USA & Radiology & $\mathrm{Y}$ & $\bar{Y}$ & $\mathrm{Y}$ & $\mathrm{Y}$ & $\mathrm{Y}$ & $\bar{Y}$ & $\bar{Y}$ & $\bar{Y}$ & $\bar{Y}$ \\
\hline Miguel-Dasit et al., 2006 (10) & Europe & Radiology & $\mathrm{Y}$ & $\bar{Y}$ & $\mathrm{Y}$ & $\mathrm{Y}$ & $\bar{Y}$ & $\mathrm{U}$ & $\mathrm{Y}$ & $\bar{Y}$ & $\bar{Y}$ \\
\hline Secil et al., 2006 (11) & Europe & Radiology & $\bar{Y}$ & $\bar{Y}$ & $\bar{Y}$ & $\mathrm{Y}$ & $\bar{Y}$ & $\bar{U}$ & $\bar{Y}$ & $\bar{Y}$ & $\bar{Y}$ \\
\hline Macmillan et al., 2007 (12) & Europe & $\begin{array}{l}\text { Emergency } \\
\text { medicine }\end{array}$ & $\bar{Y}$ & $\bar{Y}$ & $\bar{Y}$ & $\mathrm{Y}$ & $\mathrm{U}$ & $\mathrm{U}$ & $\bar{Y}$ & $\bar{Y}$ & $\bar{Y}$ \\
\hline Ha et al., 2008 (13) & Other & Radiology & $\mathrm{Y}$ & $\bar{Y}$ & $\mathrm{Y}$ & $\mathrm{Y}$ & $\bar{Y}$ & $\mathrm{Y}$ & $\mathrm{U}$ & $\bar{Y}$ & $\bar{Y}$ \\
\hline Kottachchi et al, 2010 (14) & North America/ USA & $\begin{array}{l}\text { Gastroentero } \\
\text { logy }\end{array}$ & $\bar{Y}$ & $\bar{Y}$ & $\mathrm{U}$ & $\mathrm{Y}$ & $\mathrm{Y}$ & $\mathrm{Y}$ & $\mathrm{Y}$ & $\bar{Y}$ & $\bar{Y}$ \\
\hline Donegan and Kim, 2012 (15) & North America/ USA & Orthopaedics & $\bar{Y}$ & $\bar{Y}$ & $\bar{Y}$ & $\bar{Y}$ & $\bar{Y}$ & $\bar{Y}$ & $\bar{Y}$ & $\bar{Y}$ & $\bar{Y}$ \\
\hline Winnik et al, 2012 (16) & Europe & Cardiology & $\bar{Y}$ & $\bar{Y}$ & $\mathrm{Y}$ & $\mathrm{Y}$ & $\mathrm{Y}$ & $\mathrm{Y}$ & $\mathrm{Y}$ & $\bar{Y}$ & $\bar{Y}$ \\
\hline Yoon et al, 2012 (17) & Other & Urology & $\bar{Y}$ & $\mathrm{Y}$ & $\mathrm{Y}$ & $\mathrm{Y}$ & $\bar{Y}$ & $\mathrm{Y}$ & $\mathrm{Y}$ & $\bar{Y}$ & $\bar{Y}$ \\
\hline Walsh et al, 2013 (18) & North America/ USA & $\begin{array}{l}\text { Medical } \\
\text { education }\end{array}$ & $\bar{Y}$ & $\bar{Y}$ & $\bar{Y}$ & $\bar{Y}$ & $\bar{Y}$ & $\mathrm{U}$ & $\bar{Y}$ & $\bar{Y}$ & $\bar{Y}$ \\
\hline Jorgens et al, 2014 (19) & Europe & Diabetes & $\mathrm{Y}$ & $\bar{Y}$ & $\mathrm{Y}$ & $\bar{Y}$ & $\bar{Y}$ & $\mathrm{U}$ & $\mathrm{U}$ & $\bar{Y}$ & $\bar{Y}$ \\
\hline Mutlu et al, 2015 (20) & Other & Child Psychiatry & $\bar{Y}$ & $\bar{Y}$ & $\mathrm{Y}$ & $\mathrm{Y}$ & $\mathrm{Y}$ & $\mathrm{U}$ & $\mathrm{Y}$ & $\bar{Y}$ & $\bar{Y}$ \\
\hline Elliott et al, 2016 (21) & North America/ USA & Neurosurgery & $\mathrm{Y}$ & $\bar{Y}$ & $\mathrm{Y}$ & $\mathrm{Y}$ & $\mathrm{Y}$ & $\mathrm{Y}$ & $\mathrm{Y}$ & $\bar{Y}$ & $\bar{Y}$ \\
\hline Kay et al, 2016 (22) & North America/ USA & Surgery & $\bar{Y}$ & $\bar{Y}$ & $\mathrm{Y}$ & $\mathrm{Y}$ & $\bar{Y}$ & $\mathrm{Y}$ & $\mathrm{Y}$ & $\bar{Y}$ & $\bar{Y}$ \\
\hline Shergill et al, 2017 (23) & Europe & Radiology & $\bar{Y}$ & $\bar{Y}$ & $\mathrm{Y}$ & $\bar{Y}$ & $\bar{Y}$ & $\mathrm{U}$ & $\mathrm{Y}$ & $\bar{Y}$ & $\bar{Y}$ \\
\hline Hosseini-Zijoud, 2017 (24) & Other & Nephrology & $\bar{Y}$ & $\bar{Y}$ & $\mathrm{Y}$ & $\bar{Y}$ & $\bar{Y}$ & $\mathrm{Y}$ & $\mathrm{Y}$ & $\bar{Y}$ & $\bar{Y}$ \\
\hline Orr et al, 2017 (25) & North America/ USA & Orthopaedics & $\bar{Y}$ & $\bar{Y}$ & $\mathrm{Y}$ & $\mathrm{Y}$ & $\bar{Y}$ & $\mathrm{U}$ & $\mathrm{Y}$ & $\bar{Y}$ & $\overline{\mathrm{Y}}$ \\
\hline Hoelscher et al, 2017 (26) & North America/ USA & Child Psychiatry & $\mathrm{Y}$ & $\bar{Y}$ & $\mathrm{Y}$ & $\mathrm{Y}$ & $\bar{U}$ & $\mathrm{Y}$ & $\mathrm{U}$ & $\bar{U}$ & $\bar{Y}$ \\
\hline Basu et al, 2017 (27) & North America/ USA & Paediatrics & $\mathrm{Y}$ & $\bar{Y}$ & $\mathrm{Y}$ & $\mathrm{Y}$ & $\bar{Y}$ & $\mathrm{Y}$ & $\mathrm{U}$ & $\bar{Y}$ & $\bar{Y}$ \\
\hline Nwachukwu et al., 2018 (28) & Other & Arthroscopy & $\mathrm{Y}$ & $\bar{Y}$ & $\mathrm{Y}$ & $\bar{Y}$ & $\bar{Y}$ & $\mathrm{U}$ & $\mathrm{Y}$ & $\mathrm{Y}$ & $\bar{Y}$ \\
\hline Egloff et al, 2017 (29) & North America/ USA & $\begin{array}{l}\text { Internal } \\
\text { medicine }\end{array}$ & $\bar{Y}$ & $\bar{Y}$ & $\bar{Y}$ & $\bar{Y}$ & $\bar{Y}$ & $\mathrm{Y}$ & $\mathrm{Y}$ & $\bar{Y}$ & $\bar{Y}$ \\
\hline $\begin{array}{l}\text { Komagamine and Yabuki, } \\
2018(30)\end{array}$ & Other & Primary care & $\bar{Y}$ & $\bar{Y}$ & $\mathrm{Y}$ & $\bar{Y}$ & $\bar{Y}$ & $\mathrm{U}$ & $\mathrm{Y}$ & $\bar{Y}$ & $\bar{Y}$ \\
\hline Raudenbush et al, 2018 (31) & North America/ USA & Spine & $\bar{Y}$ & $\bar{Y}$ & $\mathrm{Y}$ & $\bar{Y}$ & $\bar{Y}$ & $\mathrm{U}$ & $\mathrm{Y}$ & $\bar{Y}$ & $\bar{Y}$ \\
\hline
\end{tabular}

(Based upon questions in Munn Z, Moola S, Lisy K, Riitano D, Tufanaru C. Methodological guidance for systematic reviews of observational epidemiological studies reporting prevalence and incidence data. Int J Evid Based Healthc. 2015; 13:147-153. (3)

(Key: U Unknown, YYes) 
Table 3:

Meta-regression analysis

\begin{tabular}{|l|c|c|c|c|c|c|c|c|}
\hline & Coefficient & Lower Bound & Upper Bound & Z value & P value & Tau2 & I2 & R2 \\
\hline Duration of time frame (k=27) & -0.049 & -0.184 & 0.086 & -0.71 & 0.477 & 0.265 & $97.33 \%$ & 0.00 \\
& & & & & & & \\
\hline Publication year (k=28) & -0.022 & -0.059 & 0.019 & -1.16 & 0.245 & 0.269 & $97.34 \%$ & 0.00 \\
\hline
\end{tabular}

Analysis run using Comprehensive Meta-Analysis software, using random effects model due to high heterogeneity

Society meetings. Clin Otolaryngol Allied Sci.2001 Jun; 26(3):253-6.

8. Sprague S, Bhandari M, Devereaux PJ, Swiontkowski MF, Tornetta P, 3rd, Cook DJ, et al. Barriers to full-text publication following presentation of abstracts at annual orthopaedic meetings. J. Bone Joint Surg. Am. 2003 Jan;85(1):158-63.

9. Arrivé, L, Boelle P-Y, Dono P, Lewin M, Monnier-Cholley L, Tubiana J-M. Subsequent publication of orally presented original studies within 5 years after 1995 RSNA Scientific Assembly. Radiology. 2004 Jul; 232(2):101-6.

10. Miguel-Dasit A, Martí-Bonmatí L, Sanfeliu P, Aleixandre R. Scientific papers presented at the European Congress of Radiology 2000: publication rates and characteristics during the period 2000-2004. Eur. Radiol.2006 Feb; 16(2):445-50.

11. Secil M, Ucar G, Dicle O. Scientific papers presented at the 2000-2001 European Society of Gastrointestinal and Abdominal Radiology (ESGAR) meetings: publication rates during the period 2000-2004. Eur. Radiol.2007 Aug;17(8):2183-8.

12. Macmillan C D, Moore A K, Cook R J, Pedley D K. Abstract-topublication ratio for papers presented at scientific meetings: a quality marker for UK emergency medicine research. Emerg. Med. J. 2007 Jun; 24(6):425-6.

13. Ha TH, Yoon T Y, Goo D H, Chang S K, Seo Y L, Yun E J, et al. Publication rates for abstracts presented by Korean investigators at major radiology meetings. Korean J. Radiol.2008 Jul-Aug;9(4):303-11.

14. Kottachchi D, Nguyen G C. Quality and publication success of abstracts of randomized clinical trials in inflammatory bowel disease presented at Digestive Disease Week. Inflamm. Bowel Dis.2010 Jun;16(6):993-8.

15. Donegan D J, Kim TW, Lee G-C. Publication rates of presentations at an annual meeting of the American academy of orthopaedic surgeons. Clin. Orthop 2010 May;468(5):1428-35.

16. Winnik S, Raptis DA, Walker JH, Hasun M, Speer T, Clavien PA, et al. From abstract to impact in cardiovascular research: factors predicting publication and citation. Eur Heart J. 2012 Dec;33(24):3034-45.

17. Yoon P D, Chalasani V, Woo H H. Conversion rates of abstracts presented at the Urological Society of Australia and New Zealand (USANZ) Annual Scientific Meeting into full-text journal articles. BJU Int. 2012 Aug;110(4):485-9.

18. Walsh CM, Fung M, Ginsburg S. Publication of results of abstracts presented at medical education conferences. JAMA. 2013 Dec 4; 310(21):2307-9.

19. Jörgens V, Grüsser $M$, Schürmann $P$, Müller UA. Fate of abstracts submitted to the 2004 EASD Annual Meeting in Munich. Diabetologia. 2014 Sep; 57(9):1997-9.

20. Mutlu C, Mutlu E K, Kiliçolu AG, Yorbik Ö. From poster presentation to publication: National Congress of Child and Adolescent Psychiatry. Noro Psikiyatr Ars. 2015 Jun;52(2):111-116.

21. Elliott C A, Mehta V, Poon C, Oliver M, Gourishankar S.The fate of abstracts presented at the Annual Meeting of the Congress of Neurologic Surgeons. Open J Mod. Neurosurg.2016 Jan;6: 1-8.

22. Kay J, Memon M, de Sa D, Duong A, Simunovic N, Athwal GS, Ayeni OR. Five-year publication rate of clinical presentations at the open and closed American Shoulder and Elbow Surgeons Annual Meeting from 2005-2010. J. Exp. Orthop. 2016 Dec;3(1):21.

23. Shergill R, Kaka H, Kennedy SA, Baerlocher MO. Publication rates of abstracts presented at major interventional radiology conferences. Diagn Interv Radiol. 2017 Oct 6;23(6):435-440.

24. Hosseini-Zijoud S, Barzi F, Lotfiazar A, Einollahi B. Fate of abstracts presented at the First International Congress of Nephrology And Urology, Tehran, Iran, 2015, Nephro Urol Mon. 2017;9(3):e42541.

25. Orr J, Dunn JC, Kusnezov N, Fares AB, Waterman BR, Garcia E, Pallis M. Publication rate and impact factor for Society of Military Orthopedic Surgeons Annual Meeting Presentations, 2009-2013.Mil.Med. 2017 Nov;182(11):e1992-6.

26. Hoelscher A M, Checketts J X, Vassar M. An evaluation of the publication rate of AACAP Annual Meeting presentations from 20122013. J Am Acad Child Adolesc Psychiatry. 2017; 56: S296-7

27. Basu S, Pollack MM. Outcome of pediatric critical care medicine abstracts presented at North American academic national meetings. Pediatr Crit Care. Med. 2017 May 5:795-9.

28. Nwachukwu BU, Boddapati V, Fu MC, Rebolledo BJ, Ranawat AS, Safran MR. What is the fate of scientific abstracts presented at the International Society for Hip Arthroscopy meetings? J Hip. Preserv. Surg. 2018 Mar 12;5(2):157-61.

29. Egloff HM, West CP, Wang AT, Lowe KM, EdakkanambethVarayil J, et al. Publication rates of abstracts presented at the Society of General Internal Medicine Annual Meeting.J. Gen. Intern. Med. 2017 Jan 30;32(6): 673-8.

30. Komagamine J,Yabuki T. Full-text publication rate of abstracts presented at the Japan Primary Care Association Annual Meetings (2010-2012): a retrospective observational study. BMJ Open. 2018; 8:e021585.

31. Raudenbush B, Frost C, Okafor R, Chen C, Qui X, Mesfin A. Publication rate of podium presentations from the North American Spine Society Annual Meetings. Global Spine J. 2018 May; 8(3):273-8.

32. Uhl E, Steiger H J, Barth C, Reulen H J. Evaluation of abstracts submitted for the annual meeting of the German Neurosurgical Society 1999-unravelling a mystery. Zentralbl. Neurochir.1999;60(4):196- 201. 